\title{
Investigation by luminal perfusion of the transfer of compounds into the epididymis of the anaesthetized rat
}

\author{
T. G. Cooper and G. M. H. Waites \\ Department of Physiology \& Biochemistry, The University, Whiteknights, Reading RG6 $2 A J$, \\ Berkshire, U.K.
}

\begin{abstract}
Summary. Controlled perfusion through the lumen of the distal cauda epididymidis in the anaesthetized rat has been explored as a means of examining physiological exchanges from blood across the epididymal epithelium. The mean length of the perfused, sperm-free, tubule was $14.5 \mathrm{~cm}( \pm 1.5$ s.e.m., $n=9)$. No cholesterol, protein or sialic acid was detected in the perfusate at flow rates exceeding $10 \mu \mathrm{l} / \mathrm{min}$, but at rates of $0.4-1.2 \mu \mathrm{l} / \mathrm{min}$, protein appeared at concentrations of $0.21-0.55$ $\mathrm{mg} / \mathrm{ml}$ (i.e. secretion rates of $0.21-0.83 \mu \mathrm{g} / \mathrm{min} ; 3$ rats). Glucose was detected at all perfusion rates $(3-27 \mu \mathrm{l} / \mathrm{min})$ at concentrations of $0.06-0.58 \mathrm{~mm}(0 \cdot 8-6 \cdot 8 \%$ blood levels).

During intravenous infusions of ${ }^{3} \mathrm{H}_{2} \mathrm{O}$, radioactivity in the perfusate rapidly attained $87 \%$ blood plasma concentrations; no radioactivity was detected when carboxy-[ $\left[{ }^{14} \mathrm{C}\right]$ dextran or methoxy- $\left[{ }^{3} \mathrm{H}\right]$ inulin were infused. Radioactivity appeared in the epididymal perfusate to $1-7 \%$ of blood levels during intravenous infusions of $\mathrm{D}-\left[\mathrm{U}-{ }^{14} \mathrm{C}\right]$ glucose or $3-O$-methyl $\left[1-{ }^{3} \mathrm{H}\right]$ glucose.

This evidence suggests that the preparation is physiological and could be used to explore the dynamics of exchanges between blood and epididymis.
\end{abstract}

\section{Introduction}

The role of the epididymis in influencing the maturation and storage of spermatozoa is unclear, partly because of the difficulty of identifying secretory products of the epididymal epithelium before they are modified by spermatozoa. Earlier results have varied according to species and methods of collection. Such methods have involved post-mortem collection (Crabo, 1965; for review see White, 1973), or massaging, teasing or shaking the tissue to express 'luminal fluid' (Prasad et al., 1974; Huang \& Johnson, 1975; Shimazaki, Yamanaka, Taguchi \& Shida, 1976), but these clearly risk contamination with blood, lymph or cytoplasmic constituents leaking from cells.

Other data come from collections of fluid from the cauda epididymidis by fistulation or from the vas deferens by cannulation of conscious rams (White \& Wales, 1961; Voglmayr et al., 1977) and bulls (Sexton, Amann \& Flipse, 1971), or of anaesthetized rabbits (Jones \& Glover, 1973), rats (Back, Shenton \& Glover, 1974), guinea-pigs and hamsters (Back \& Shenton, 1975). The technique of micropuncture has yielded information on the contents of proximal regions of the epididymis of rats (Levine \& Marsh, 1971; Hinton, Setchell \& White, 1976; Turner, Hartmann \& Howards, 1977; Levine \& Kelly, 1978) and hamsters (Jessee \& Howards, 1976). The values reported, however, represented the steady-state conditions existing within the epididymal lumen at the time of collection, in the presence of spermatozoa.

The study reported here involved flushing the spermatozoa from a segment of the cauda epididymidis and then perfusing the lumen of this segment in the anaesthetized rat. A similar technique has been reported by Wong \& Yeung (1978) for examination of water and electrolyte exchanges. 


\section{Materials and Methods}

\section{Surgical procedure}

Male CD rats (Charles River, U.K. Ltd, Manston, Kent) weighing between 309 and $534 \mathrm{~g}$ had free access to water and diet 86 (Dixon \& Sons (Ware) Ltd, U.K.). The rats were anaesthetized with sodium pentobarbitone (Nembutal: Abbott Laboratories; $60 \mathrm{mg} / \mathrm{kg}$, i.p.) and a tracheal cannula was inserted. Polyvinylchloride cannulae (PVC; $0.5 \mathrm{~mm}$ i.d. $0.8 \mathrm{~mm}$ o.d.; Dural Plastics, Dural, N.S.W., Australia) containing heparin (25 i.u./ml) in $154 \mathrm{~mm}$-sodium chloride were introduced into the external jugular vein and common carotid artery. Rectal temperature was monitored and maintained at $37^{\circ} \mathrm{C}$.

The testes and epididymides were exteriorized through incisions in the scrotum and immersed in baths of mineral oil maintained at $33-34^{\circ} \mathrm{C}$. The surgical procedure was similar to that described by Wong \& Yeung (1978) except that: (1) the vas deferens close to the cauda epididymidis was cannulated first with a hypodermic needle $(0.2 \mathrm{~mm}$ o.d.; gauge 27$)$ attached to a PVC catheter $(0.2 \mathrm{~mm}$ i.d., $0.5 \mathrm{~mm}$ o.d.); (2) the epididymal contents were next removed by gently flushing the perfusion fluid out of a loop of the tubule in the cauda epididymidis close to the caudal flexure; (3) a drawn-out PVC cannula was then tied into the emptied epididymal tubule.

The lumen of the epididymis was perfused from the cauda epididymidis towards the vas deferens, using a piston-driven pump (C. F. Palmer Ltd, Kingston-upon-Thames, Surrey). The rate of perfusion was calculated from the weight of the perfusate obtained during the sampling period. These rates varied because of variations in catheter and tubule diameters. An initial high rate of about $25 \mu \mathrm{l} / \mathrm{min}$ for $20 \mathrm{~min}$ was used to ensure that the luminal contents were removed before the perfusate was collected, and then perfusion rates were varied from 1.2 to $15.4 \mu \mathrm{l} / \mathrm{min}$.

At the end of some of the experiments the perfusion fluid was replaced by rubber latex (Gerrard \& Co. Ltd, Sussex) injected through the cannula in the vas deferens. The latex cast was obtained after digestion of the tissue in $1 \mathrm{M}-\mathrm{KOH}$, and its length was measured.

\section{Perfusion fluids}

The principal perfusion solution was unbuffered $168 \mathrm{mM}$-sodium chloride (isosmotic with epididymal plasma, $336 \mathrm{mosmol} / \mathrm{kg}$ : Levine \& Marsh, 1971). In later experiments this was buffered to epididymal $\mathrm{pH}(6.85)$ with $50 \mathrm{~mm}$-morpholinopropanesulphonic acid (MOPS).

\section{Infusion solutions}

Radioactive compounds were obtained from the Radiochemical Centre (Amersham, U.K.) unless otherwise stated. Water-soluble compounds were dissolved in $154 \mathrm{~mm}$-sodium chloride and infused into the jugular vein at $0.5-1.0 \mathrm{ml} / \mathrm{h}$. In 6 rats, carboxy $-\left[{ }^{14} \mathrm{C}\right]$ dextran $(\mathrm{mol}$. wt 20000 ; sp. act. $2 \cdot 16 \mu \mathrm{Ci} / \mathrm{mg}$; New England Nuclear Chemicals, U.S.A.) and ${ }^{3} \mathrm{H}_{2} \mathrm{O}$ (sp. act. 5 $\mathrm{mCi} / \mathrm{ml}$ ) were infused at $63 \mathrm{nCi} / \mathrm{min}$ and $1.0 \mu \mathrm{Ci} / \mathrm{min}$ respectively for up to $2 \mathrm{~h}$. In 4 rats methoxy- $\left[{ }^{3} \mathrm{H}\right]$ inulin (sp. act. $200 \mathrm{mCi} / \mathrm{mmol}$ ) and $\mathrm{D}-\left[\mathrm{U}-{ }^{14} \mathrm{C}\right.$ glucose $($ sp. act. $281 \mathrm{mCi} / \mathrm{mmol}$ ) were infused at $16.7-125 \mathrm{nCi} / \mathrm{min}$ and $0.27-3.88 \mu \mathrm{Ci} / \mathrm{min}$ respectively for $45-60 \mathrm{~min}$. Both $\left[{ }^{14} \mathrm{C}\right]$ dextran and $\left[{ }^{3} \mathrm{H}\right]$ inulin were shown to contain only macromolecular-bound radioactivity by gel filtration on $15 \mathrm{~cm}$ columns of Sephadex G-25 (Pharmacia). In 4 rats the non-metabolizable sugar 3-O-methyl-D- $\left[1-{ }^{3} \mathrm{H}\right]$ glucose (sp. act. $7.7 \mathrm{Ci} / \mathrm{mmol}$ ) was infused at $0.58-1.45 \mu \mathrm{Ci} / \mathrm{min}$ for $90 \mathrm{~min}$.

\section{Analyses of the perfusate}

Protein was estimated by a modification of the method of Hartree (1972) on 5-10 $\mu$ l perfusate. Total sialic acids were estimated (Warren, 1959) after hydrolysis in $0.1 \mathrm{M}-\mathrm{H}_{2} \mathrm{SO}_{4}$ for 1 
h at $80^{\circ} \mathrm{C}$. Cholesterol was measured by the Liebermann-Burchard reaction (Cook \& Rattray, 1958). Glucose was estimated by the glucose oxidase method (Huggett \& Nixon, 1957) in 25-50 $\mu \mathrm{l}$ samples of perfusate. Acid supernatants from blood $(50 \mu \mathrm{l})$ were brought to $\mathrm{pH} 6.6$ with 0.71 M-morpholinoethanesulphonic acid (MES) plus $2 \cdot 26 \mathrm{M}-\mathrm{K}_{2} \mathrm{CO}_{3}$.

\section{Experimental protocol}

Perfusions of the epididymal lumen continued during and after intravenous infusions. Consecutive 10 or 15 min samples of epididymal perfusate were stored on ice. Midway through each collection period, blood (about $80 \mu \mathrm{l}$ ) was sampled from the cannula in the carotid artery, and either centrifuged immediately for estimation of $\left[{ }^{14} \mathrm{C}\right]$ dextran, ${ }^{3} \mathrm{H}_{2} \mathrm{O}$ and $\left[{ }^{3} \mathrm{H}\right]$ methylglucose, or $50 \mu \mathrm{l}$ were diluted in $500 \mu \mathrm{l} 3 \%(\mathrm{v} / \mathrm{v})$ perchloric acid, mixed and then centrifuged for estimations of blood glucose, $\left[{ }^{14} \mathrm{C}\right]$ glucose and $\left[{ }^{3} \mathrm{H}\right]$ inulin.

The radioactivity (d.p.m./ $\mu$ l) in the perfusate was plotted against time, and the ratio of the activity in the perfusate to that in plasma sampled during its collection was calculated at each time interval throughout the experimental period (120-180 min). The interval between the appearance of radioactivity in the lumen and its arrival in the collecting tube was not taken into account in the calculation of this ratio. The standard short length of the cannula in the vas deferens $(4 \mathrm{~cm})$ had a volume of about $1 \mu \mathrm{l}$ which would be flushed out in $30 \mathrm{sec}$ at the slowest perfusion rate used. When the length of the perfused tubule was included in the volume, the flushout time was about $3 \mathrm{~min}$, i.e. less than one-third of the time of sample collection.

\section{Liquid scintillation spectrophotometry}

Samples $(10-50 \mu \mathrm{l})$ were added with $500 \mu \mathrm{l}$ water to $5 \mathrm{ml}$ of a scintillant containing $0.1 \mathrm{~g}$ POPOP and $2.5 \mathrm{~g}$ PPO per litre of toluene:Triton X-100 $(2: 1, \mathrm{v} / \mathrm{v})$. Radioactivity was estimated on a NE 8310 (Nuclear Enterprises, Edinburgh) or Tricarb 3255 (Packard). Corrections for counting efficiency and isotope spill during dual isotope counting were made by external standardization.

\section{Results}

The mean \pm s.e.m. length of the perfused segment was $14.5 \pm 1.5 \mathrm{~cm}$ (range $9-20 \mathrm{~cm}, 9$ rats), with an estimated volume of 13-31 $\mu$.

No cholesterol, protein or sialic acid was detectable in perfusates collected at perfusion rates exceeding $10 \mu \mathrm{l} / \mathrm{min}$, despite blood plasma concentrations of $0.70 \pm 0.03 \mathrm{mg} / \mathrm{ml}(n=9), 70.7 \pm$ $2.0 \mathrm{mg} / \mathrm{ml}(n=16)$ and $3.7 \pm 0.3 \mu \mathrm{mol} / \mathrm{ml}(n=6)$, respectively. When perfusion rates were reduced to $0.4-1.2 \mu \mathrm{l} / \mathrm{min}$, protein was detected in the perfusate in 3 rats, at concentrations of $0.21-0.55 \mathrm{mg} / \mathrm{ml}$, i.e. secretion rates of $0.21-0.83 \mu \mathrm{g} / \mathrm{min}$.

Glucose was secreted into the perfusate at $0.4-6 \cdot 3 \mathrm{nmol} / \mathrm{min}$ during perfusion at rates of $0.21-25.3 \mu \mathrm{l} / \mathrm{min}$. Concentrations varied from $0.06-0.58 \mathrm{~mm}$ (6 rats: $0.20 \pm 0.05$ (s.e.m.) $\mathrm{mm}$ ), and were from 0.8 to $6.8 \%$ of the glucose concentration in blood sampled at the end of the perfusion $(7.4 \pm 0.3 \mathrm{~mm}$; range $6.7-9.7 \mathrm{~mm}, 9$ rats). No accumulation of glucose occurred during seven periods of stopped flow (ranging from 10 to $80 \mathrm{~min}$ ) in 4 rats. During intravenous infusions of $\left[{ }^{14} \mathrm{C}\right]$ glucose and $\left[{ }^{3} \mathrm{H}\right]$ methylglucose, blood glucose concentrations were raised $(9.6-14.8 \mathrm{~mm}, 8$ rats) as were those in the perfusates $(0.24-1.25 \mathrm{~mm}, 3$ rats).

During infusions of ${ }^{3} \mathrm{H}_{2} \mathrm{O}$, radioactivity in the perfusate attained a mean value of $87 \%$ of plasma levels (range $71-102 \%$; 4 rats), within 15-30 min from the start of the infusion, and then reached a plateau of $86-96 \%$ (Text-fig. 1). In 2 other rats which suffered blood loss and exhibited dyspnoea, perfusate radioactivity attained values of only 39 and $57 \%$ those of the plasma after 15-30 min, and maximal values of 44 and $72 \%$. These and subsequent preparations with haemorrhage were discarded. 


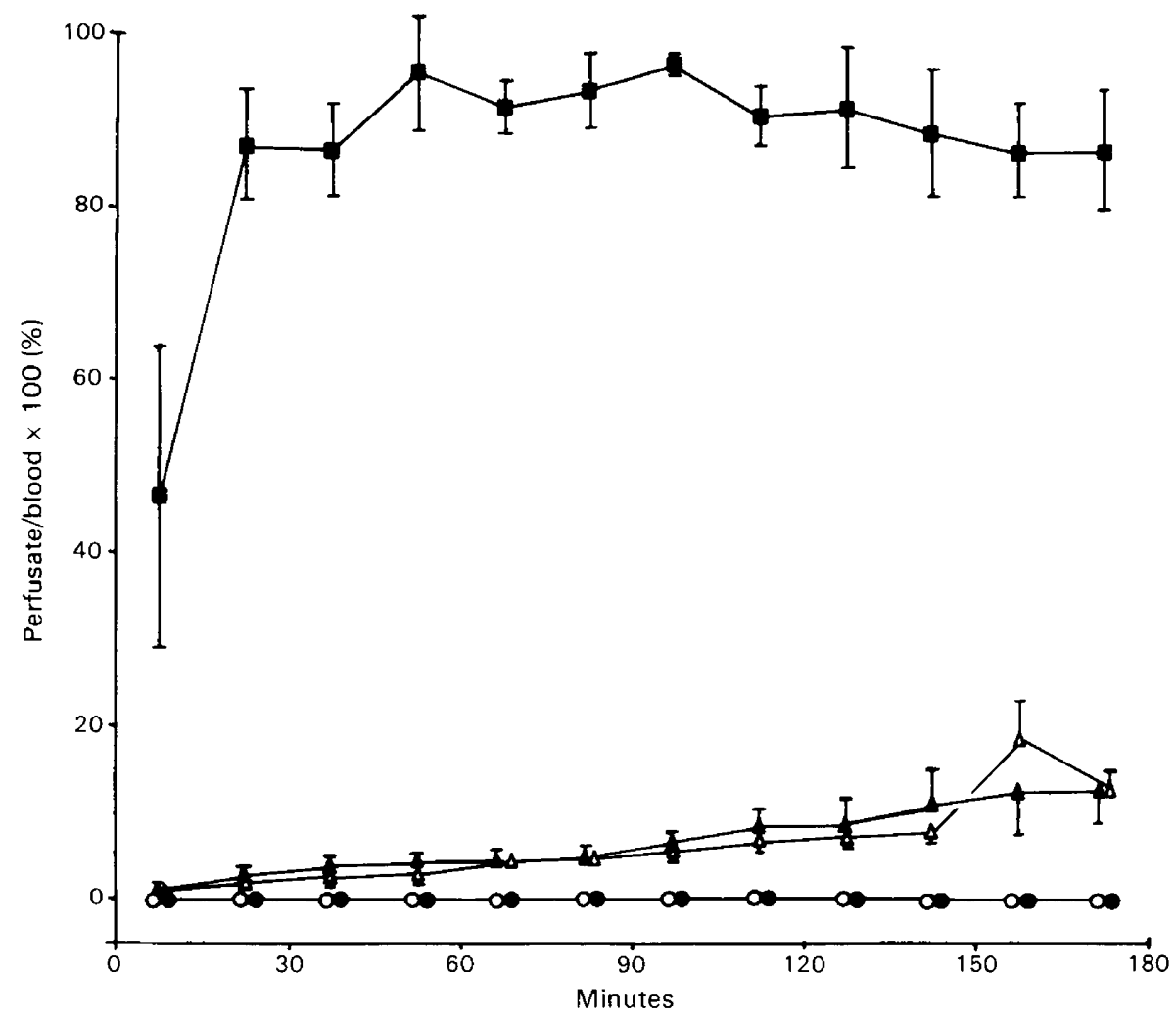

Text-fig. 1. The permeability of the perfused cauda epididymidis of the rat. The ratio of the radioactivity in the perfusate to that in blood was calculated at 15 -min intervals during and after intravenous infusions of: ${ }^{3} \mathrm{H}_{2} \mathrm{O}\left(\mathrm{Q}, 4\right.$ epididymides), $\left[{ }^{14} \mathrm{C}\right]$ glucose $\left(\triangle, 3\right.$ epididymides), $\left[{ }^{3} \mathrm{H}\right]$ methylglucose ( $\triangle, 8$ epididymides), $\left[{ }^{3} \mathrm{H}\right]$ inulin $\left(\mathbf{O}, 4\right.$ epididymides) and $\left[{ }^{14} \mathrm{C}\right]$ dextran $(\mathrm{O}, 6$ epididymides). The molecular weights of these substances were 22, 183, 194, 5200 and 20000 respectively.

By contrast, no radioactivity was detected in the lumen of the cauda epididymidis whatever the perfusion rate $(1.7-26.6 \mu \mathrm{l} / \mathrm{min})$ when $\left[{ }^{14} \mathrm{C}\right]$ dextran $(6$ rats $)$ or $\left[{ }^{3} \mathrm{H}\right]$ inulin $(4$ rats $)$ was infused into the general circulation, and radioactivity in blood remained elevated for $2-3 \mathrm{~h}$. Similar uptake or radioactivity into the epididymal lumen occurred during infusions of $\left[{ }^{14} \mathrm{C}\right]-$ glucose (into unbuffered perfusate) and $\left[{ }^{3} \mathrm{H}\right]$ methylglucose (buffered perfusate), reaching $1-7 \%$ of blood levels during the infusions and $7-17 \%$ after them (Text-fig. 1).

\section{Discussion}

The present study indicates that perfusion of the lumen of the epididymis in the anaesthetized rat is a valid means of examining the transfer of blood-borne compounds into the epididymal lumen.

The preparation was evaluated by a number of criteria. The absence of cholesterol, protein and sialic acids at high perfusion rates, despite substantial concentrations in blood, suggests that no gross leakage through the epithelium occurred during the cannulation or perfusion. The cauda epididymidis was also impermeable to large molecules such as dextran (mol. wt 20000) and inulin (mol. wt 5200) introduced into the bloodstream. $\left[{ }^{3} \mathrm{H}\right]$ Inulin has previously been shown to 
be excluded from the lumen of the cauda epididymidis of the hamster (Howards, Jessee \& Johnson, 1976). Wong \& Yeung (1978) introduced $\left[{ }^{3} \mathrm{H}\right]$ inulin into the lumen of the cauda epididymidis of rats to measure water resorption and did not detect any radioactivity in the plasma from the deferential vein which drains this region. The site of this retention or exclusion may be the tight junctions between epithelial cells which prevent lanthanum in the blood and pyroantimonate in the lumen from migrating between the intercellular spaces in the epididymis (Friend \& Gilula, 1972).

The appearance of protein in the perfusate at low perfusion rates provides further evidence of the normal functioning of the perfused epididymis, confirming reports of protein secretion by Wong \& Yeung (1978). There is a high concentration of protein in epididymal plasma from rats (Back et al., 1974) and yet a barrier has been shown to exist towards entry of large molecules from blood. The proteins appearing in the perfusate, therefore, are those specific to the epididymis (Koskimies \& Kormano, 1975; Cameo \& Blaquier, 1976). Tritiated water in plasma equilibrated with the perfusate in the epididymal lumen within $30 \mathrm{~min}$; in hamsters the equilibration time after micropuncture was 50 min (Howards et al., 1976).

The presence of glucose in the perfusate is of interest since only trace or non-detectable amounts of reducing hexose have been found in epididymal fluid from conscious rams (White \& Wales, 1961; Voglmayr et al., 1977), slaughtered bulls (Crabo, 1965; Wales, Wallace \& White, 1966) or anaesthetized rabbits (Jones \& Glover, 1973), and no glucose was detected in freshly collected epididymal contents of the rat (T. G. Cooper, unpublished data). The metabolism of glucose by epididymal spermatozoa demonstrated in vitro could explain the absence of glucose from epididymal plasma. Whether or not the permeability of the epididymis to glucose is altered by perfusion of buffered saline through the epididymal canal flushed free of its normal contents cannot be determined from the present study. The absence of accumulation of glucose during the periods of stopped-flow could be explained by a different permeability under these conditions, or reflect the utilization by the epididymal epithelium of the sugar when it is not removed by continual perfusion. The present study supports the concept of a dynamic transfer of glucose between blood and epididymal fluid postulated by White \& Wales (1961) and White (1973), and shown to occur in the oviducts of rabbits (Leese \& Jeffries, 1977). This could be a source of energy for spermatozoa in situ, which have been shown to utilize glucose in vitro (Geer, Kelly, Pohlman \& Yemm, 1975; Brooks, 1976).

This work was supported by Grant G/976/020 from the Medical Research Council.

\section{References}

Back, D.J. \& Shenton, J.C. (1975) A comparison of the composition of epididymal plasma from the cauda epididymidis of the rat, hamster and guinea-pig. Experientia 31, 464-465.

Back, D.J., Shenton, J.C. \& Glover, T.D. (1974) The composition of epididymal plasma from the cauda epididymidis of the rat. J. Reprod. Fert. 40, 211-214.

Brooks, D.E. (1976) Activity and androgen control of glycolytic enzymes in the epididymis and epididymal spermatozoa in the rat. Biochem. J. 156, 527-537.

Cameo, M.S. \& Blaquier, J.A. (1976) Androgencontrolled specific proteins in rat epididymis. $J$. Endocr. 69, 47-55.

Cook, R.P. \& Rattray, J.B.M. (1958) Methods of isolation and estimation of sterols. In CholesterolChemistry, Biochemistry and Pathology, pp. 117143. Ed. R. P. Cook. Academic Press, New York.
Crabo, B. (1965) Studies on the composition of epididymal content in bulls and boars. Acta vet. scand., Suppl. 5.

Friend, D.S. \& Gilula, N.B. (1972) Variations in tight and gap junctions in mammalian tissue. J. Cell Biol. 53, 758-776.

Geer, B.W., Kelly, K.R., Pohlman, T.H. \& Yemm, S.J. (1975) A comparison of rat and Drosophila spermatozoan metabolisms. Comp. Biochem. Physiol. 50B, 41-50.

Hartree, E.F. (1972) Determination of protein: a modification of the Lowry method that gives a linear photometric response. A nalyt. Biochem. 48, 422-427.

Hinton, B.T., Setchell, B.P. \& White, R.W. (1976) The determination of myo-inositol in micropuncture samples from the testis and epididymis of the rat. $J$. Physiol., Lond. 265, 14-15P. 
Howards, S.S., Jessee, S.J. \& Johnson, A.L. (1976) Micropuncture studies of the blood-seminiferous tubule barrier. Biol. Reprod. 14, 264-269.

Huang, H.F.S. \& Johnson, A.D. (1975) Amino acid composition of epididymal plasma of mouse, rat, rabbit and sheep. Comp. Biochem. Physiol. 50B, 359-362.

Huggett, A.St.G. \& Nixon, D.A. (1957) Use of glucose oxidase, peroxidase and $\mathrm{O}$-dianisidine in determination of blood and urinary glucose. Lancet $\mathbf{i i}$, 368-370.

Jessee, S.J. \& Howards, S.S. (1976) A survey of sperm, potassium and sodium concentrations in the tubular fluid of the hamster epididymis. Biol. Reprod. 25, 626-631.

Jones, R. \& Glover, T.D. (1973) The collection and composition of epididymal plasma from the cauda epididymidis of the rabbit. J. Reprod. Fert. 34, 395403.

Koskimies, A.I. \& Kormano, M. (1975) Protein in fluids from different segments of the rat epididymis. $J$. Reprod. Fert. 43, 345-358.

Leese, H.J. \& Jefiries, K.S. (1977) Evidence for the facilitated diffusion of glucose into rabbit oviductal fluid. J. Reprod. Fert. 51, 93-97.

Levine, N. \& Kelly, H. (1978) Measurement of $\mathrm{pH}$ in the rat epididymis in vivo. J. Reprod. Fert. 52, 333-335.

Levine, N. \& Marsh, D.J. (1971) Micropuncture studies of the electro-chemical aspects of fluid and electrolyte transport in individual seminiferous tubules, the epididymis and vas deferens. J. Physiol., Lond. 213, 557-570.

Prasad, M.R.N., Rajalakshmi, M., Gupta, G., Dinakar, N., Arora, R. \& Karkun, T. (1974) Epididymal environment and maturation of spermatozoa. In Male Fertility and Sterility, pp. 459-478. Eds R. E. Mancini \& L. Martini. Academic Press, New York.

Sexton, T.J., Amann, R.P. \& Flipse, R.J. (1971) Free amino acids and protein in rete testis fluid, vas deferens plasma, accessory sex gland fluid and seminal plasma of the conscious bull. J. Dairy Sci. 54, 412-416.

Shimazaki, J., Yamanaka, H., Taguchi, I. \& Shida, K. (1976) Free amino acids in the caput and the cauda epididymis of adult rats. Endocr. jap. 23, 149-156.

Turner, T.T., Hartmann, P.K. \& Howards, S.S. (1977) In vivo sodium, potassium and sperm concentrations in the rat epididymis. Fert. Steril. 28, 191-194.

Vogimayr, J.K., Musto, N.A., Saksena, S.K., BrownWoodman, P.D.C., Marley, P.B. \& White, I.G. (1977) Characteristics of semen collected from the cauda epididymidis of conscious rams. $J$. Reprod. Fert. 49, 245-251.

Wales, R.G., Wallace, J.C. \& White, I.G. (1966) Composition of bull epididymal and testicular fluid. J. Reprod. Fert. 12, 139-144.

Warren, L. (1959) The thiobarbituric acid assay of sialic acid. J. biol. Chem. 234, 1971-1975.

White, I.G. (1973) Biochemical aspects of spermatozoa and their environment in the male reproductive tract. J. Reprod. Fert., Suppl. 18, 225-235.

White, I.G. \& Wales, R.G. (1961) Comparison of epididymal and ejaculated semen of the ram. $J$. Reprod. Fert. 2, 225-237.

Wong, P.Y.D. \& Yeung, C.H. (1978) Absorptive and secretory functions of the perfused rat cauda epididymidis. J. Physiol., Lond. 275, 13-26.

Received 21 August 1978 